\title{
ARTM (Augmented Reality Teaching Methodology)
}

\author{
Anmol Kumar \\ SVKM's NMIMS Mukesh Patel School of \\ Technology Management and Engineering
}

\author{
Akanksha Sharma \\ SVKM's NMIMS Mukesh Patel School of \\ Technology Management and Engineering
}

\begin{abstract}
The current technological scenario is so volatile that it changes every day, and to remain in stream with it we need to implement some of these advancements in our current educational systems. One of the new emerging technology is Mixed Reality (MR) / Extended Reality (XR) which is garnering a lot of attention in the digital world. Augmented Reality is a part of this system which can extensively be used to bring improvements in the current teaching environment. This paper focuses on the potential of Augmented Reality as an innovative learning medium. It will analyze different fields of study and stress upon the point of how Augmented Reality Teaching Methods (ARTM) can be implemented in them. In the end detailed comparison among all subjects where ARTM can be applied effectively will be delivered along with the proposed method of how it can be integrated with the present education methodology.
\end{abstract}

\section{General Terms}

Augmented Reality, Artificial Reality, Instructor Interfaces, E-learning Tools, Learning Tools

\section{Keywords}

Mixed Reality, Augmented Reality Teaching Method, ARTM.

\section{INTRODUCTION}

Mixed Reality is the concept coined with the famous term of virtuality continuum (Paul milgram, 1994) which describes the technologies of Augmented Reality and Augmented Virtuality between the purely virtual and real environments.

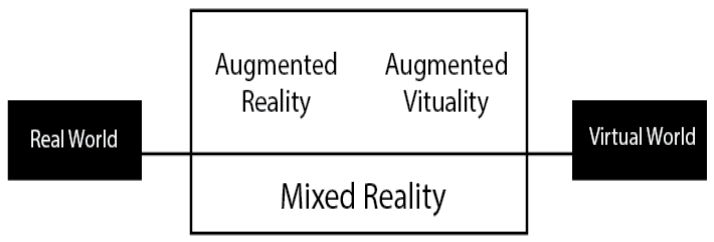

Figure 1 Basic diagram depicting the concept of Virtuality Continuum

While both Augmented Reality (AR) and Augmented Virtuality (AV) have huge potential as an emerging technology. Our current technological society, though has accepted and realized the potential of the former more readily than the latter, as it delivers more relatable results for users. AR applications when put in alliance with educational system, it offers an exciting and unique learning experience by softening the boundaries between the real world and the virtual world. The areas where AR has been implemented so far are the educational systems, gaming department, hospital and health related turf and many more! AR can be realized by different hardware, which are basically divided into wearable (e.g. smart phones and tablets) and non-wearable (e.g. smart watches or smart glasses) devices. (Sabrina Romina Sorko, 2019)
While the gaming industry and the health care (Colin J. McCarthy, 2019, pp. 1-2) have very innovative and interesting ways of using the technology of AR, let's focus on how it can be integrated in the education system. AR can be used to explain the intricate details of a diagram, to understand the inner parts and working of a complicated machine or some inaccessible part or reports of a body part for better understanding of an ailment. Our paper would not limit itself to any particular kind of hardware like Head-mounted Display (HMD) and will try to explain how AR can be used in every prospect of teaching with most of the devices and would also try to explore any further methods of teaching through ARTM.

\section{ARTM FOR PRIMARY GRADE STUDENTS}

Primary studies comprise of learning the alphabets, numbers, rhymes etc. Primary school is basically the stage where children are introduced to the world for the first time. All this could be made more attractive by using ARTM. For example,

Alphabet learning becomes far interesting if an apple appears in front of them while they learn the character " $A$ " (CansuOranç, 2019), giving our old teaching methods a digital touch.

Animals appearing in front of them as they read about it, in $3 \mathrm{D}$ form with their signature cries as well as animated forms that move around, makes them remember those animals far easily.

The basic arithmetic (addition, subtraction, multiplication, division), basic geometry presented by taking their real-life actions in consideration. How adding one candy with another will make it two and again adding one more will result in three candies.

Literature is made more fun when, while reading a poem about shoes, the characters appear alongside. The facial expressions they are learning about are shown in action on the screen.

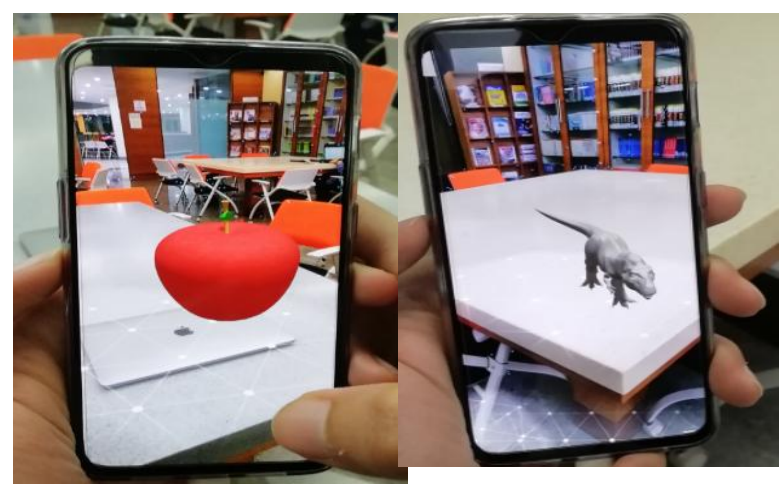

Figure 2 A simple Augmented Reality application that can be used to instantiate various objects and animals for students' immersive experience. 


\section{IMPLEMENTING ARTM IN MIDDLE SCHOOL}

The fundamentals of mathematics, science and literature starts from the middle school. We have the opportunity of developing students' interest in different fields and what better way than to let them immerse themselves in the interactive deep end of technology like Augmented Reality. Through ARTM we can make them visualize the concepts of studies like general materials, basic geography, history and detailed concepts of problem solving like general algebra in much better and comprehensive manner.

Let us take few middle school concepts for example and try to understand the way AR can be used to achieve these examples:

Students learn about the Solar System, the celestial bodies, constellation in physics (Mustafa F., 2019), ARTM can help them visualize it.

History can be really hard to relate with, but with our method students can see the events of History happening before their eyes and relive it. Looking at the horrifying gas chamber and the colony created by Hitler, feeling the events of the world's most shocking decade that reshaped our world, giving them a chance to relate to it with the help of ARTM.

The biological classification of living species is introduced in middle school science which is a huge chart and with a lot of new examples that students have never even heard of before. It can be made easier to learn when they can actually see it in front of them with ARTM.

\section{ARTM FOR HIGH SCHOOL}

The stage where, the way you are taught gives direction to your future. The fundamentals learned in primary and middle school are implemented at this stage of school-life.

Let's take some examples of High-school study subjects to espouse the effectiveness of teaching in concurrence to the Augmented Reality technology:

For a biology student, ARTM could help him/her understand the very details of human anatomy thoroughly. The whole systems inside human/animal body can be comprehended with this technology. Students learning botany can also be benefitted when they can see even the rarer plants not available in the laboratories come alive through AR.

A mathematics student can understand the basics of every proven equation, its origin from the root, as well as its way of implementation. Word problems could be interpreted well in $3 \mathrm{D}$ in $\mathrm{AR}$ making fields like trigonometry more interesting.

A commerce student can study the stocks, real estate and economics through ARTM for deeper understanding of the subject scenario. The current economic trending news can be broadcasted on their HMDs.

Physics is an essential area of study for science students and students have difficulty in understanding some of the finer details of this subject. ARTM can provide the necessary helping hand in this regard. Newton's laws of motion, the principles of conservation of energy, watching Julius Caesar's infamous assassination and the chaos it ensued, the magic of Shakespearian writings living and breathing in front of their eyes. The deep meanings inside the poems of romantic writers like John Keats can be felt through not just writing but experiencing the joy of it through AR.

\section{UNIVERSITY \& PROFESSIONAL LEVEL ARTM}

University is the stage of education where you start to get familiar with the specifics of the field you have chosen for the profession one has chosen to pursue. This familiarity can be made even more detailed by introducing ARTM in the University curriculum which will make this journey even more enjoyable, also at this stage students will study the concepts and structures of different aspects of machines, anatomy or society in great detail and this where ARTM will excel in making this detailed information available to students at their fingertips.

While we believe every major can be benefitted by ARTM, the students of science are already availing this technology in many parts of the world.

Computer Science: The students of Computer Science are required to study the architecture of various systems along with all the scripting language knowledge. These architectures say for example architecture of 8086 and its working will become so much easier to decipher when they have an allinclusive 3D model of the diagram. Furthermore, students of Computer Science have the advantage of getting to know how to develop any kind of Augmented Reality Application themselves. They can develop an AR application for any concept they find difficult themselves.

Medical Science: The fields of medical sciences are where Augmented Reality has already proved its usefulness and it continues to do so even now. It is not an exaggeration to say that this technology is saving a life while this text is being read. Even the amateur doctors can seek help from experienced surgeons in serious and difficult cases of surgery to avoid any kind of mistakes and reduce the risk of life. Particularly, in surgery using laparoscopy (a type of surgical procedure that allows a surgeon to access the inside of the abdomen and pelvis without having to make large incisions in the skin), endoscopy (a nonsurgical procedure used to examine a person's digestive tract) are very intricate and any mistake can prove to be fatal for the patient.

Mechanical Engineering: The comprehensive diagram of parts and explicit details inside a machine can be depicted by ARTM with ease, and students can even have detailed AR models along with the workshop where they can learn how to use a particular machinery as well its inner mechanism. Having a HoloLens while performing an experiment is not that incomprehensible and it will improve the quality of education automatically.

Paleontologists and archaeologists can study different eras (example Paleolithic, Mesolithic) and bone structures of various species and artefacts found in it, through the help of Augmented Reality.

An aspiring fashion designer can make an apparel virtually real and have a mannequin or a model wear it and examine how it looks. This practical application can bring revolutionary change in the fashion industry and can catalyze the influx of many new ideas. 
Table 2. Institutions that are already implementing ARTM

\begin{tabular}{|c|c|c|c|}
\hline $\begin{array}{l}\text { Sr. } \\
\text { No. }\end{array}$ & $\begin{array}{l}\text { Institution } \\
\text { Name }\end{array}$ & Place & Execution \\
\hline 1. & $\begin{array}{l}\text { Sevenoaks } \\
\text { School }\end{array}$ & $\begin{array}{l}\text { United } \\
\text { Kingdom }\end{array}$ & $\begin{array}{l}\text { They researched on the } \\
\text { technology in } \\
\text { coordination with } \\
\text { other schools, } \\
\text { experimented their } \\
\text { usage pattern the } \\
\text { findings were shared. }\end{array}$ \\
\hline 2. & $\begin{array}{c}\text { EON } \\
\text { Entrepreneur } \\
\text { School }\end{array}$ & $\begin{array}{l}\text { Irvine, CA, } \\
\text { USA }\end{array}$ & $\begin{array}{l}\text { They used AR to make } \\
\text { students gain } \\
\text { entrepreneurial skills } \\
\text { through project-based } \\
\text { learning on real } \\
\text { market/industry } \\
\text { projects. }\end{array}$ \\
\hline 3. & $\begin{array}{l}\text { Chandler } \\
\text { Traditional } \\
\text { Academy }\end{array}$ & $\begin{array}{l}\text { Arizona, } \\
\text { USA }\end{array}$ & $\begin{array}{l}\text { They are using zSpace } \\
\text { (combination of } \\
\text { Augmented Reality } \\
\text { and Virtual Reality) to } \\
\text { work with human } \\
\text { heart. }\end{array}$ \\
\hline 4. & $\begin{array}{c}\text { The } \\
\text { University } \\
\text { of } \\
\text { Wisconsin- } \\
\text { Madison }\end{array}$ & $\begin{array}{l}\text { Wisconsin, } \\
\text { USA }\end{array}$ & $\begin{array}{l}\text { The Dow Day protest } \\
\text { was emulated on an } \\
\text { Augmented Reality } \\
\text { Application that the } \\
\text { students can use on } \\
\text { their mobile devices } \\
\text { and point at different } \\
\text { places on the campus } \\
\text { and find out exactly } \\
\text { what was happening at } \\
\text { that very spot on the } \\
\text { day of protest. }\end{array}$ \\
\hline 5. & $\begin{array}{l}\text { Community } \\
\text { College of } \\
\text { Beaver } \\
\text { County }\end{array}$ & $\begin{array}{c}\text { Pennsylvania, } \\
\text { USA }\end{array}$ & $\begin{array}{l}\text { CCBC students have } \\
\text { the facility of an } \\
\text { application that they } \\
\text { can use to experience } \\
\text { AR enabled content } \\
\text { such as video, } \\
\text { animation, audio, and } \\
\text { websites. }\end{array}$ \\
\hline 6. & $\begin{array}{l}\text { Cal Poly } \\
\text { Pomona }\end{array}$ & $\begin{array}{c}\text { Pomona, CA, } \\
\text { USA }\end{array}$ & $\begin{array}{l}\text { An application of Cal } \\
\text { Poly lets students to } \\
\text { learn about the } \\
\text { historical significance } \\
\text { of different locations } \\
\text { through the use of } \\
\text { Augmented Reality } \\
\text { Technology just by } \\
\text { opening the app and } \\
\text { pointing it towards the }\end{array}$ \\
\hline
\end{tabular}

\begin{tabular}{|c|c|c|c|}
\hline & & place. \\
\hline 7. & $\begin{array}{c}\text { Simpson } \\
\text { College }\end{array}$ & $\begin{array}{c}\text { Redding, CA, } \\
\text { USA }\end{array}$ & $\begin{array}{c}\text { While not using it for } \\
\text { education purpose the } \\
\text { Simpson College is } \\
\text { using AR to depict } \\
\text { what students' life is } \\
\text { like in their college by } \\
\text { triggering a video } \\
\text { through the image } \\
\text { present on the banner } \\
\text { when the students } \\
\text { point their mobile } \\
\text { camera at it. }\end{array}$ \\
\hline & & \\
\hline
\end{tabular}

\section{CONCLUSION}

There are many different ways in which ARTM can be integrated in the general schedule of teaching in schools. The idea that we propose is simultaneous teaching i.e., the teachers help students understand the concepts through standard lecture first and later on through Augmented Reality implementation on a tablet or an HMD that all students have access to, where this can be used to clarify the doubts and help students to understand the concept in a complete manner.

In all of the above given examples, we can agree upon the fact that Augmented Reality has proven itself to be a great asset in teaching methodology. Even the most complex problems can be simplified into most commonly understandable solutions when they are explained with ARTM. We are able to use this technology in various mobile platforms like smartphones, tablets, holo-lenses etc. that we can bring to our classrooms, lecture halls, labs and medical wards, where they can be used to help us to flourish our knowledge further. Hence ARTM should be encouraged to be used appositely and efficiently by our educational systems for the betterment of quality of pedagogy.

\section{REFERENCES}

[1] A Taxonomy of Mixed Reality Visual Displays Paul Milgram, Fumio Kishino 7th International young Scientist Conference on computational Science - Existing Teaching Practices in Augmented Reality Alexandra Klimova*, Anna Bilyatdinova, Andrey Karsakov

[2] Advances in Virtual and Augmented Realityd-Exploring the Role in Health-care Education Colin J. McCarthy, MD *, Raul N. Uppot, MD International Journal of Child-Computer Interaction.

[3] Learning from the real and the virtual worlds: Educational use of augmented reality in early childhood Cansu Oranç *, Aylin C. Küntay

[4] Integrating augmented reality into problem-based learning: The effects on learning achievement and attitude in physics education Mustafa FIDAN, Meric TUNCEL 9th Conference on Learning Factories 2019

[5] Potentials of Augmented Reality in Training Sabrina Romnia Sorko*, Magdalena Brunnhofer Department of Psychology, Koç University, Istanbul, Turkey 
[6] Relations between student motivation, immersion and learning outcomes in location-based augmented reality settings Yiannis Georgiou*, Eleni A. Kyza Cyprus University of Technology, Cyprus

[7] 7th World Conference on Educational Sciences, (WCES2015), 05-07 February 2015, NovotelAthens Convention Center, Athens, Greece Utilising Mobile-Augmented Reality for Learning Human Anatomy Siti Salmi Jamaliab*, Mohd Fairuz Shiratuddin, Kok Wai Wong, Charlotte L. Oskam

[8] 9th Conference on Learning Factories 2019 Hybrid learning environments by data-driven augmented reality
Dörte Sonntaga, Georgia Albuquerqueb, Marcus Magnorb, Oliver Bodensieka.

[9] Computers \& Education Integrating augmented reality into problem-based learning: The effects on learning achievement and attitude in physics education.

[10] Augmented reality for STEM learning: A systematic review María-Blanca Ibáñez, Carlos Delgado-Kloos

[11] 9th Conference on Learning Factories 2019 Potentials of Augmented Reality in Training Sabrina Romina Sorkoa*, Magdalena Brunnhofera 